\title{
Sebaran Material Padatan Tersuspensi dan Fosfat di Perairan Semarang, Jawa Tengah
}

\author{
I Made Rifaldy Puja Utama, Lilik Maslukah*, Sri Yulina Wulandari \\ Departemen Oseanografi, Fakultas Perikanan dan Ilmu Kelautan, Universitas Diponegoro \\ JI. Prof. H. Soedarto S.H, Tembalang, Semarang, Jawa Tengah 50275 Indonesia \\ ${ }^{*}$ Corresponding author, e-mail : lilik_masluka@yahoo.com
}

\begin{abstract}
ABSTRAK : Sungai Banjir Kanal Barat dan Banjir Kanal Timur merupakan sungai besar yang berperan dalam mempengaruhi nilai kualitas perairan Semarang. Sungai ini membawa material dan limbah yang berasal dari darat kemudian mengalir ke laut melalui muara sungai. Penelitian ini bertujuan untuk mengetahui nilai konsentrasi zat padat tersuspensi (MPT) dan fosfat serta pola distribusinya. Penelitian ini dilaksanakan pada bulan Februari 2019 dengan menggunakan metode deskriptif kuantitatif. Metode penentuan lokasi menggunakan purposive sampling pada 22 stasiun yang dapat merepresentasikan wilayah muara dan laut. Penentuan MPT secara gravimetri dan fosfat menggunakan metode asam askorbat. Hasil konsentrasi MPT berkisar antara 50-290 mg/L dan fosfat $0,95-0,16 \mathrm{mg} / \mathrm{L}$. Pola distribusi secara horisontal MPT menunjukkan lebih tinggi di daerah dekat pantai dan pola sebaran vertikal menunjukkan lebih tinggi di permukaan $(0,2 \mathrm{~m})$ dibanding di bagian bawah $(0,8 \mathrm{~m})$. Pola sebaliknya ditemukan pada sebaran fosfat dengan nilai lebih tinggi di dasar dan pola sebaran spasialnya menunjukkan konsentrasi tinggi ditemukan di wilayah timur yaitu di Muara Sungai Banjir Kanal Timur. Sungai Banjir Kanal Timur memberikan kontribusi yang besar terhadap unsur hara fosfat terlarut.
\end{abstract}

Kata Kunci : Material Padatan Tersuspensi; Fosfat; Semarang

\section{Distribution of Suspensed Particulate Material and Phosphate in Semarang Waters, Central Java}

\begin{abstract}
The Banjir Kanal Barat and Banjir Kanal Timur River are major rivers that play a role in influencing the quality value of Semarang waters. This river carries material and waste originating from the land and then flows out to the sea through the river mouth. This study aims to determine the concentration value of suspended solids (MPT) and phosphate and the distribution pattern. This research was conducted in February 2019, using descriptive quantitative methods. The method of determining the location uses purposive sampling at 22 stations that can represent the estuary and sea areas. Gravimetric and phosphate determination of MPT using the ascorbic acid method. The results of MPT concentrations ranged from 50-290 mg / L and phosphate from 0.95 to $0.16 \mathrm{mg} / \mathrm{L}$. Spatial distribution of MPT shows a high concentration in the coastal area and vertically, the distribution is higher at the surface $(0.2 \mathrm{~m})$ than at the bottom $(0.8 \mathrm{~m})$. This pattern is different from the phosphate which is found to be higher at the bottom with its spatial distribution showing a high concentration in the eastern region, namely in the estuary of Banjir Kanal Timur. This estuary of Banjir Kanal Timur has a large contribution to phosphate ions.
\end{abstract}

Keywords : Suspended Particulate Material; SPM; Phosphate; Semarang

\section{PENDAHULUAN}

Perairan Semarang merupakan perairan yang memiliki banyak sungai bermuara di dalamnya. Dua diantaranya adalah Sungai Banjir Kanal Barat dan Sungai Banjir Kanal Timur. Peningkatan aktivitas rumah tangga dan perkembangan industri di sekitar aliran sungai ini secara nyata memberikan masukan sedimen yang dapat mempengaruhi kekeruhan. Masuknya material tersuspensi dari daratan melalui sungai ke perairan pantai mempunyai peranan penting dalam membawa elemen-elemen kimia, termasuk nutiren (Tungka et al., 2016). Padatan tersuspensi dan 
nutrien akan berpengaruh terhadap kualitas perairan tersebut. Pengaruh tersebut berupa menurunnya kemampuan perairan dalam meneruskan cahaya dan mempengaruhi pertumbuhan.

Masuknya nutrien dari daratan melalui sungai ke perairan pantai mempunyai peranan penting dalam menstimulasi proses biologi di perairan tersebut (Gunduz, et al., 2011), termasuk peningkatan pertumbuhan fitoplankton (Paerl, et al., 2009). Tingginya konsentrasi nutrien di lingkungan perairan memiliki dampak positif dan negatif. Dampak positif disebabkan karena meningkatnya produksi fitoplankton dan selanjutnya berpengaruh terhadap produksi ikan. Sedangkan dampak negatif terjadi penurunan oksigen terlarut dan berkembangnya jenis fitoplankton atau algae yang berbahaya serta dapat merubah komposisi spesies (Prep, 2009). Kondisi ini sering disebut sebagai eutrofikasi. Hasil penelitian Prayitno \& Afdal (2019) di Perairan Teluk Jakarta menemukan bahwa unsur $\mathrm{P}$ lebih berpengaruh terhadap variabilitas fitoplakton.

Beberapa penelitian tentang material padatan tersuspensi (MPT) pernah dilakukan oleh beberapa peneliti sebelumnya oleh Febrianto \& Latifah (2017) dan Subiyanto (2017). Penelitian yang dilakukan sebelumnya ini menggunakan data citra satelit. Penelitian MPT menggunakan data citra dengan beberapa algoritma masih mengalami bias (Prasetiyo et al., 2019). Data kualitas perairan lainnya seperti fosfat di Perairan Semarang juga telah dilakukan oleh Maslukah et al. (2019) dan Tungka et al. (2016), namun belum dikaji pola sebarannya secara vertikal dan belum dikaitkan dengan keberadaan MPT. Maslukah et al. (2019) menyatakan bahwa konsentrasi MPT berkaitan dengan sumber atau penyebab berkurangnya ion phospat.

Penelitian ini bertujuan untuk mengetahui pola sebaran MPT pada dua lapisan kedalaman (permukaan dan dekat dasar) dan nutrien fosfat menggunakan data pengambilan dilapangan serta pola persebarannya sebagai indikator kualitas perairan di Perairan Semarang, Jawa Tengah.

\section{MATERI DAN METODE}

Materi yang digunakan dalam penelitian ini adalah data primer dan data sekunder. Data primer terdiri data konsentrasi MPT dan fosfat. Data sekunder yang digunakan dalam penelitian ini meliputi: Peta Rupa Bumi Digital Semarang (BAKOSURTANAL). Metode penentuan titik sampling menggunakan purposive sampling method yaitu penentuan lokasi penelitian yang hanya mengambil beberapa daerah yang mempresentasikan keadaan keseluruhan (Hadi, 2004). Pengambilan sampel dilakukan pada 22 stasiun dan dibagi menjadi 3 kelompok perairan. Stasiun 1, 2, 3, 4, 5, 22 mewakili daerah lepas pantai sekitar muara Banjir Kanal Timur. Stasiun 6, 7, 8, 9, $10,11,12,13,14,15$, mewakili daerah pelabuhan. Stasiun 16, 17, 18, 19, 20, 21 mewakili daerah lepas pantai muara Banjir Kanal Barat.

Sampel air diambil menggunakan botol nansen dan dibawa ke laboratorium untuk dianalisa kadar MPT dan fosfat. Pengambilan sampel air dilakukan pada kedalaman 0,2 $\mathrm{m}$ dan 0,8 $\mathrm{m}$ dari total kedalaman air. Pengambilan sampel dilakukan pada saat kondisi surut.

Analisis material padatan tersuspensi menggunakan metode gravimetri (Alaerts dan Santika (1987). Kertas saring yang digunakan dalam filter adalah whatman 42, yang sebelumnya telah dilakukan pengeringan. Sampel yang disaring sebanyak 1 liter dengan bantuan vacuum pump. Konsentrasi MPT dihitung dengan menggunakan rumus :

$$
\mathrm{MPT}=\frac{(a-b)}{c} m g / l
$$

Keterangan : MPT = Material padatan tersuspensi $(\mathrm{mg} / \mathrm{L}) ; \mathrm{a}=$ Berat kertas saring dan berat MPT yang berada di kertas saring $(\mathrm{mg}) ; b=$ Berat kertas saring $(\mathrm{mg}) ; \mathrm{c}=$ Volume sampel air $(\mathrm{I})$

Analisa konsentrasi fosfat dilakukan secara asam askorbat dengan menggunakan spektrofotometer. Metode ini menggunakan prinsip dalam suasana asam yaitu ammonium molibdate dan potassium antimoniltartat bereaksi dengan ortofosfat membentuk senyawa asam fosfomolibdat kemudian direduksi oleh asam askorbit menjadi kompleks biru molibdenum (APHA, 1992). Nilai absorbansi diukur pada spektrofotometer dengan panjang gelombang $885 \mathrm{~nm}$. Analisis statistik korelasi digunakan untuk mengetahui kekuatan hubungan antara konsentrasi fosfat dan MPT. 


\section{HASIL DAN PEMBAHASAN}

Berdasarkan hasil penelitian didapatkan konsentrasi Material padatan tersuspensi (MPT) pada perairan Semarang bervariasi, yaitu berkisar antara $50-290 \mathrm{mg} / \mathrm{L}$ di dua kedalaman. Konsentrasi MPT tertinggi berada di stasiun 5 pada kedalaman $0,8 \mathrm{~m}$ dan terendah di stasiun 8 pada kedalaman 0,8 $\mathrm{m}$. Data konsentrasi MPT disajikan pada Tabel 2 dan peta pola persebaran disajikan pada Gambar 1 dan 2.

Pola sebaran konsentrasi material padatan tersuspensi secara horisontal yaitu sama di kedalaman $0,2 \mathrm{~m}$ dan $0,8 \mathrm{~m}$ yaitu semakin menurun kearah laut. Konsentrasi tertinggi di kedalaman 0,2 $\mathrm{m}$ dan 0,8 $\mathrm{m}$ didominasi dengan daerah dekat daratan. Hal tersebut terjadi karena aliran sungai merupakan sumber utama material suspensi.

Pola sebaran vertikal (Tabel 1) menunjukan bahwa konsentrasi MPT permukaan dan dasar tidak selalu sama pola persebarannya. Hal ini terkait pergerakan arus dan aktivitas perairan lainnya, seperti lalu lintas kapal. Demikian halnya juga pengaruh aliran muara sungai dari daratan. Satriadi dan Widada (2004) menjelaskan bahwa muara sungai berperan cukup penting dalam proses transpor sedimen dari darat menuju ke laut dan pola sebarannya di laut selanjutnya dipengaruhi oleh proses-proses fisika oseanografi seperti arus, gelombang, dan pasang surut. Hasil penelitian yang telah dilakukan oleh Hendrawan et al. (2016) di Perairan Teluk Benoa, Bali juga mendapatkan adanya variasi konsentrasi MPT secara vertikal yaitu pada lapisan permukaan memiliki nilai lebih tinggi dibanding lapisan tengah, tetapi lapisan dekat dasar menunjukkan lebih tinggi.

Tabel 1. Konsentrasi Material Padatan Tersuspensi

\begin{tabular}{|c|c|c|c|}
\hline \multirow{2}{*}{ Stasiun } & \multirow{2}{*}{ Kedalaman Perairan (m) } & \multicolumn{2}{|c|}{ Konsentrasi (mg/L) } \\
\hline & & $0,2 \mathrm{~m}$ & $0,8 \mathrm{~m}$ \\
\hline 1 & 2 & 136,4 & 198,5 \\
\hline 2 & 4 & 144 & 277,5 \\
\hline 3 & 2,5 & 72 & 167,5 \\
\hline 4 & 4 & 80,5 & 64,5 \\
\hline 5 & 5 & 67 & 290 \\
\hline 6 & 5 & 147,5 & 282,5 \\
\hline 7 & 3 & 143 & 63 \\
\hline 8 & 3 & 149 & 50 \\
\hline 9 & 7 & 82 & 221 \\
\hline 10 & 9 & 162,5 & 201 \\
\hline 11 & 3 & 142 & 103 \\
\hline 12 & 4 & 185 & 160,5 \\
\hline 13 & 7 & 184,5 & 152 \\
\hline 14 & 6 & 180 & 178,5 \\
\hline 15 & 4 & 184 & 159,5 \\
\hline 16 & 4 & 102,5 & 65 \\
\hline 17 & 6 & 94,5 & 83,5 \\
\hline 18 & 8 & 74 & 76 \\
\hline 19 & 7 & 166 & 185,5 \\
\hline 20 & 4 & 189 & 184 \\
\hline 21 & 4 & 158,5 & - \\
\hline 22 & 1,5 & 179,5 & - \\
\hline Rata-rata & 4,7 & 137,4 & 159,1 \\
\hline Minimal & 1,5 & 67 & 50 \\
\hline Maksimal & 9 & 189 & 290 \\
\hline
\end{tabular}

Ket : - (tidak ada data) 
Journal of Marine Research Vol 10, No.1 Februari 2021, pp. 89-96

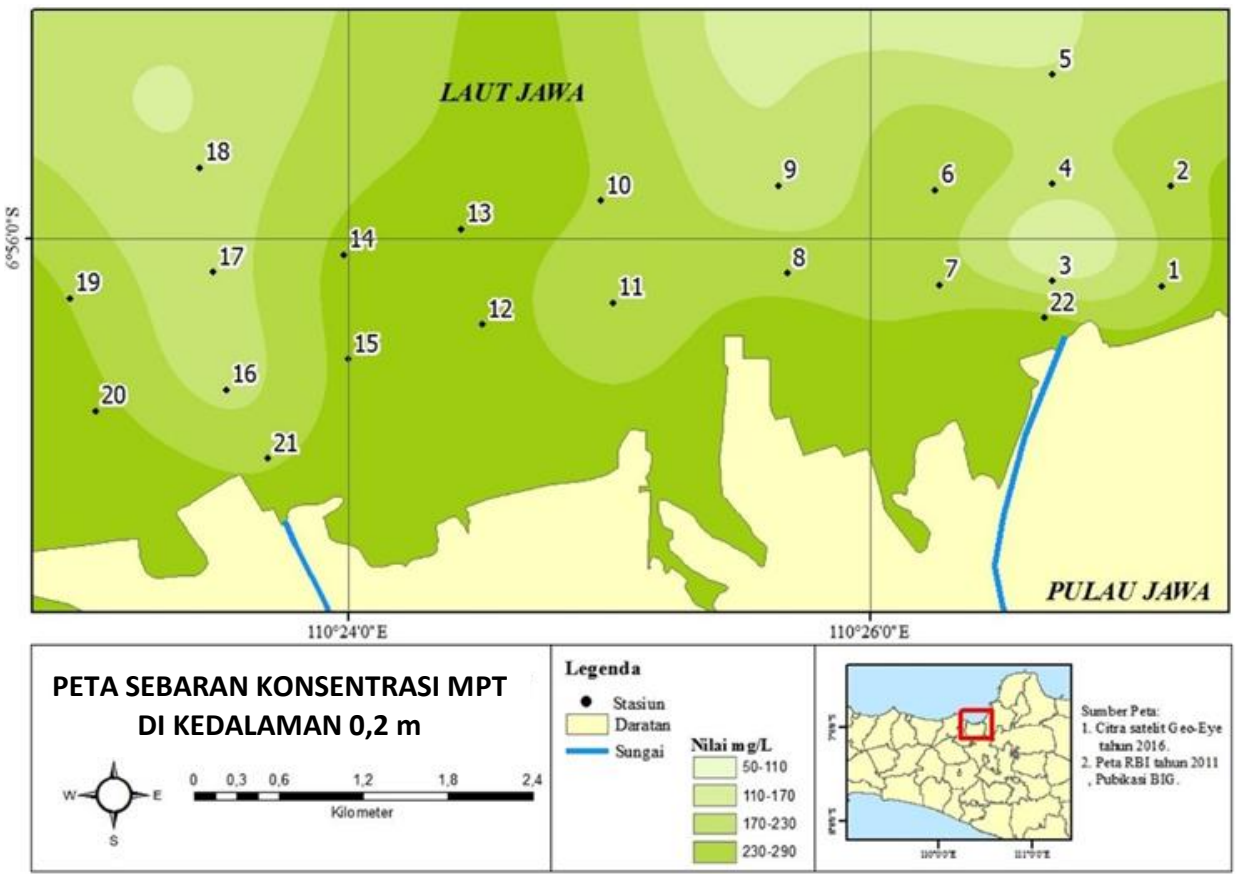

Gambar 1. Pola Persebaran MPT Kedalaman 0,2 m

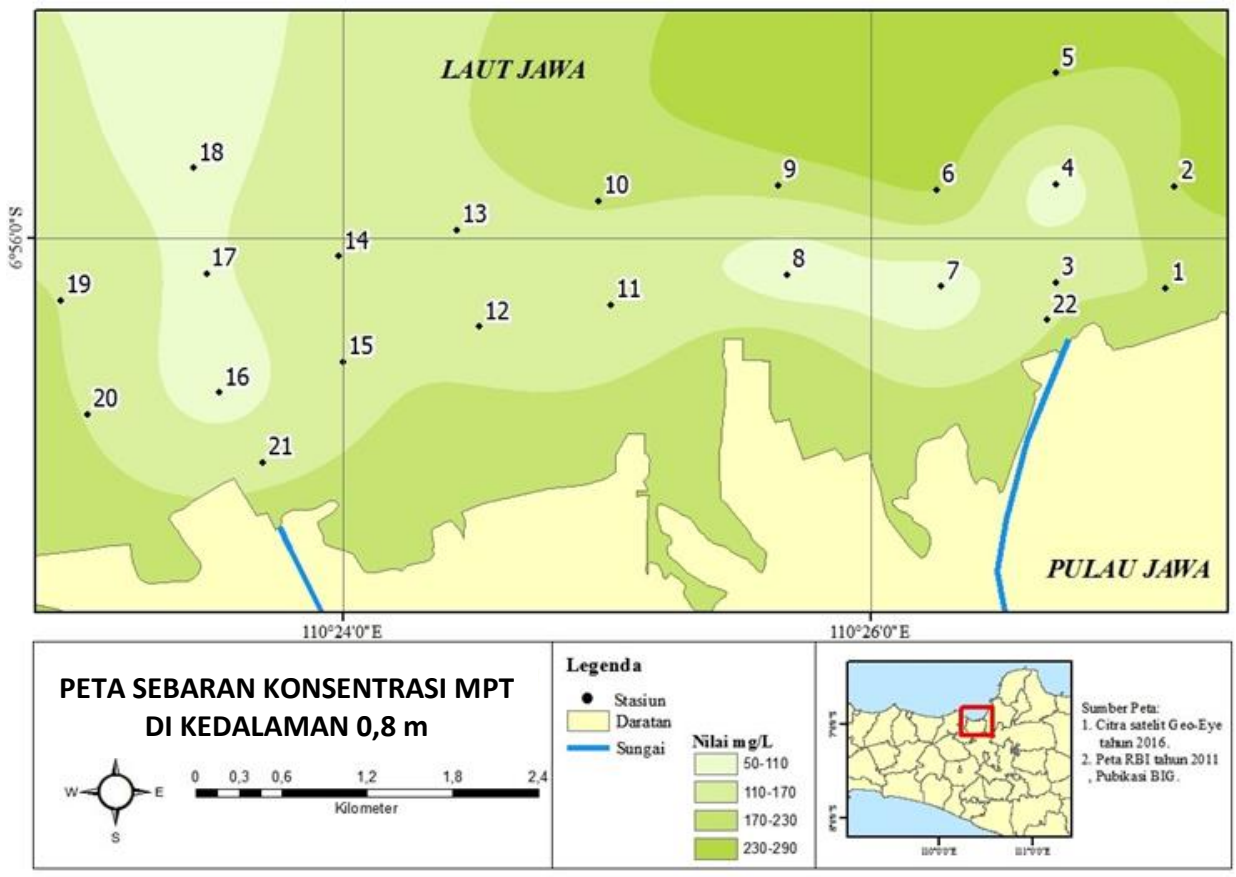

Gambar 2. Pola Persebaran Sedimen Tersuspensi Kedalaman 0,8 m

Berdasarkan nilai rerata keseluruhan (Tabel 1) memperlihatkan bahwa konsentrasi tinggi ditemukan pada kedalaman dekat dasar $(0,8 \mathrm{~m})$. Pola ini sama dengan hasil penelitian yang dilakukan oleh Shabari et al. (2019) di Muara Kaliboyo, Pekalongan dengan pola konsentrasi rendah ditemukan pada permukaan dan nilainya bertambah tinggi dengan bertamahnya kedalaman. Dibanding hasil penelitian sebelumnya oleh Pristiawan et al. (2015) di Muara Banjir Kanal Barat, Semarang didapatkan konsentrasi MPT hasil pengukuran lapangan berada pada kisaran 24,7-186,50 mg/L. 


\section{Sebaran Konsentrasi Fosfat}

Nilai konsentrasi fosfat pada Perairan Semarang bervariasi, yaitu berkisar antara 0,095 $0,164 \mathrm{mg} / \mathrm{L}$ di dua kedalaman. Konsentrasi fosfat terendah berada di stasiun 17 kedalaman $0,2 \mathrm{~m}$ dan tertinggi di stasiun 5 pada kedalaman 0,8 m. Data konsentrasi fosfat disajikan pada Tabel 2, peta pola persebaran disajikan pada Gambar 3 dan 4.

Persebaran konsentrasi fosfat di kedalaman 0,2 m pada perairan muara Banjir Kanal Timur yaitu semakin kearah laut konsentrasinya semakin rendah. Didapatkan bahwa pada stasiun 3 dimana letaknya berada di dekat muara memiliki nilai konsentrasi tertinggi diikuti dengan stasiun 4 dan 5. Menurut Ulqodry et al. (2010), konsentrasi fosfat pada umumnya mengalami persebaran dengan kuantitas yang menurun ke arah laut. Namun di kedalaman 0,8 m konsentrasi fosfat yang dimiliki berbanding terbalik dengan konsentrasi di kedalaman 0,2 $\mathrm{m}$, yaitu semakin kearah laut konsentrasinya semakin tinggi. Maslukah et al. (2014) menjelaskan bahwa konsentrasi fosfat dapat ditemukan lebih tinggi di dekat dasar $(0,8 \mathrm{~m})$ akibat diffusi fosfat serta resuspensi dari sedimen. Resuspensi sedimen akan diikuti adanya proses desorpsi nutrient dari sedimen sehingga menambah konsentrasi nutrient dalam air laut (Prartono dan Hasena, 2009). Selanjutnya Dzialowski et al. (2008) menjelaskan bahwa proses resuspensi dapat menyebabkan sedimen yang berada di dasar laut naik ke kolom air dan menyebabkan elemen kimia termasuk fosfat yang berada di dasar laut juga ikut terangkat ke kolom air. Maslukah et al. (2020) menjelaskan ada keterkaitan konsentrasi ion fosfat dengan konsentrasi $\mathrm{P}$ dalam partikel yang keberadaannya berkaitan dengan MPT (total suspended).

Gambar 3 dan 4 memperlihatkan kondisi muara sungai Banjir Kanal Timur memperlihatkan nilai konsentrasi ion fosfat yang lebih tinggi dibanding muara sungai Banjir Kanal Barat dan pada kedalaman $0,8 \mathrm{D}$ memiliki konsentrasi melebihi $0,13 \mathrm{ppm}$ (Hipertrofik) pada stasiun 5 . Tingginya konsentrasi ion $\mathrm{P}$ ini berkaitan dengan konsentrasi MPT yang paling tinggi dibandingkan dengan stasiun lainnya.

\section{Hubungan Material Padatan Tersuspensi dan Fosfat di Kedalaman 0,2 m dan 0,8 m}

Nilai korelasi antara MPT dan fosfat pada penelitan ini dibutuhkan untuk mengetahui seberapa besar hubungan konsentrasi MPT dan fosfat. Hasil korelasi disajikan pada Tabel 3.

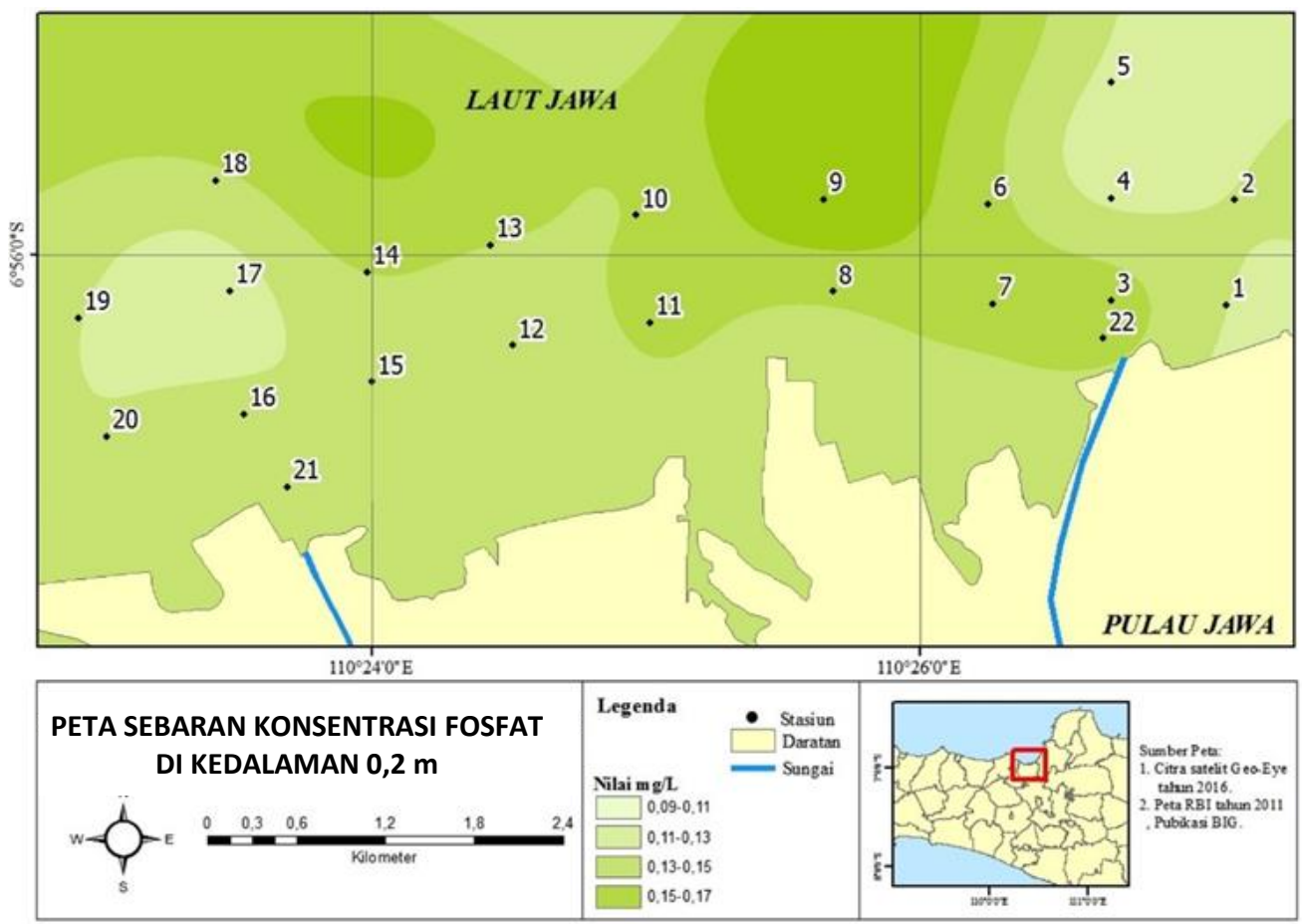

Gambar 3. Peta Persebaran Fosfat di Kedalaman 0,2D 
Tabel 2. Konsentrasi Fosfat

\begin{tabular}{cccc}
\hline & Stasiun Pengamatan & Fosfat 0,2D $(\mathrm{mg} / \mathrm{L})$ & Fosfat 0,8D $(\mathrm{mg} / \mathrm{L})$ \\
\hline \multirow{2}{*}{ Banjir Kanal } & 3 & 0,121 & 0,117 \\
Barat & 4 & 0,097 & 0,127 \\
& 5 & 0,096 & 0,164 \\
\hline \multirow{3}{*}{ Pelabuhan } & 8 & 0,119 & 0,149 \\
& 9 & 0,141 & 0,157 \\
Banjir Kanal & 10 & 0,116 & 0,137 \\
Timur & 11 & 0,118 & 0,137 \\
& 16 & 0,102 & 0,103 \\
& 17 & 0,095 & 0,102 \\
& 18 & 0,112 & 0,114 \\
& Rata-rata & 0,112 & 0,131
\end{tabular}

Tabel 3. Tabel Perhitungan Korelasi di Kedalaman 0,2D dan 0,8D

\begin{tabular}{llll}
\hline & 0,2D & MPT & FOSFAT \\
\hline MPT & Pearson Correlation & 1 & 0,218 \\
& Sig. (2-tailed) & & 0,545 \\
Fosfat & $\mathrm{N}$ & 10 & 10 \\
& Pearson Correlation & 0,218 & 1 \\
& Sig. (2-tailed) & 0,545 & \\
& $\mathrm{~N}$ & 10 & 10 \\
& 0,8D & MPT & FOSFAT \\
MPT & Pearson Correlation & 1 & $0,639^{*}$ \\
& Sig. (2-tailed) & & 0,047 \\
& $\mathrm{~N}$ & 10 & 10 \\
Fosfat & Pearson Correlation & $0,639^{*}$ & 1 \\
& Sig. (2-tailed) & 0,047 & 10 \\
\hline
\end{tabular}

*. Correlation is significant at the 0.05 level (2-tailed).

Tabel 3 memperlihatkan bahwa ada korelasi kuat antara MPT terhadap ion fosfat pada kedalaman 0,8 dengan koefisien korelasi 0,61. Hal ini dapat menjelaskan bahwa keberadaan P di dasar dipengaruhi sebesar $61 \%$ oleh MPT. Sedangkan di dekat permukaan (0,2 D) hanya sedikit dipengaruhi oleh MPT. Hubungan ini menjelaskan adanya pemakain ion P oleh fitoplankton, akibat ketersediaan cahaya di lapisan permukaan. Material padatan tersuspensi di permukaan cenderung didominansi oleh phytoplankton (bahan organik) dan adanya pemakaian fosfat oleh fitoplankton ini menyebabkan konsentrasinya menjadi rendah. Hal ini mengakibatkan hubungan lemah antara MPT terhadap fosfat dipermukaan, namun memiliki korelasi kuat pada lapisan dekat dasar $(0,8 D)$. 


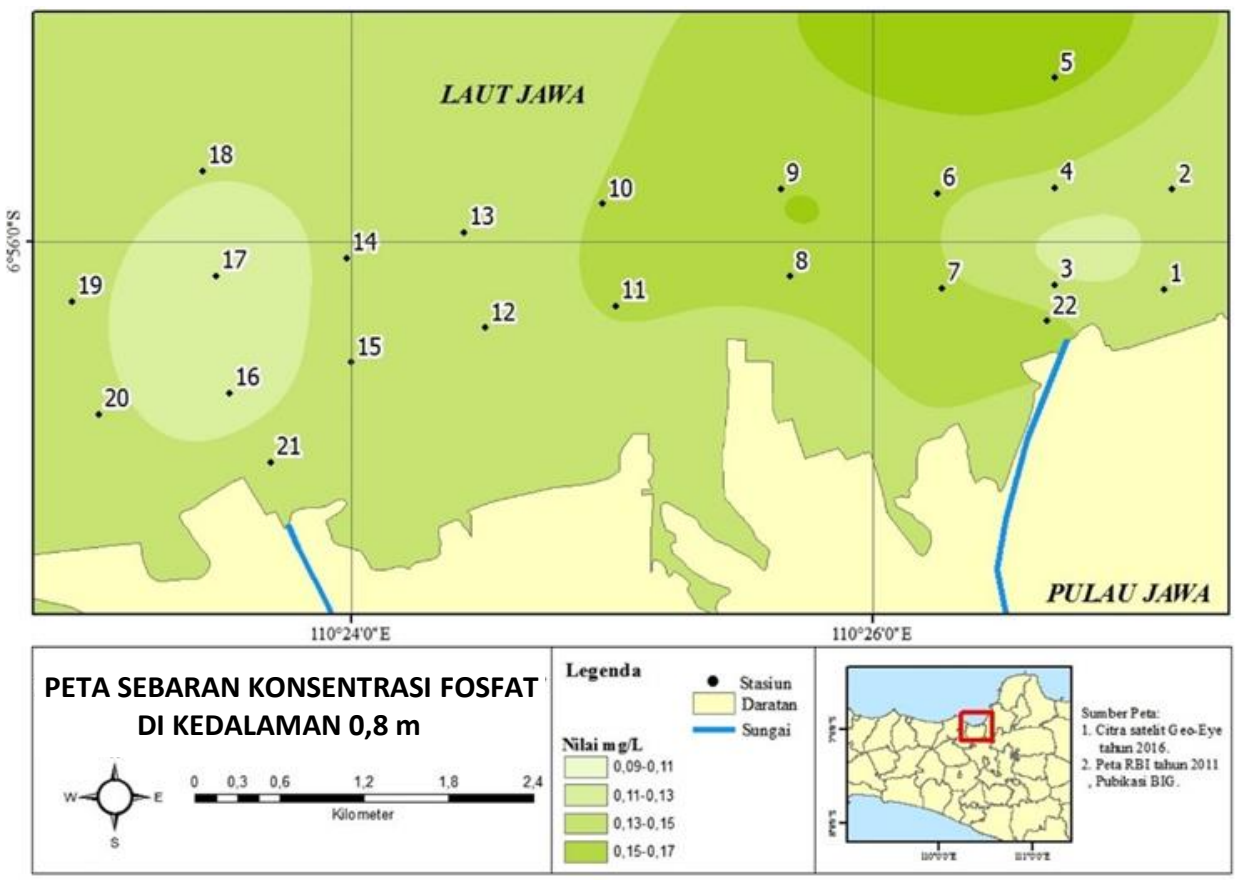

Gambar 4. Peta Persebaran Fosfat di Kedalaman 0,8D

\section{KESIMPULAN}

Berdasarkan hasil penelitian Perairan Semarang memiliki konsentrasi MPT antara 67-89 $\mathrm{mg} / \mathrm{L}$ pada kedalaman 0,2 $\mathrm{m}$ dan $50-290 \mathrm{mg} / \mathrm{L}$ pada kedalaman $0,8 \mathrm{~m}$. Berdasarkan nilai rerata keseluruan MPT ditemukan lebih tinggi di dekat dasar perairan dengan nilai mencapai 137,4 mg/L dipermukaan dan $159 \mathrm{mg} / \mathrm{L}$ pada kedalaman dekat dasar. Pengaruh aliran sungai sebagai sumber material tersuspensi mempengaruhi pola sebaran ini. Pola kebalikan terjadi pada pola persebaran fosfat, yang ditemukan lebih tinggi pada kedalaman dekat dasar. Pada kedalaman 0,2 m, konsentrasi ion fosfat berkisar antara 0,95-0,14 mg/L dan pada kedalaman 0,8 $\mathrm{m}$ antara 0,10$0,16 \mathrm{mg} / \mathrm{L}$. Pola persebaran MPT dan fosfat di kedalaman 0,2 $\mathrm{m}$ dan 0,8 $\mathrm{m}$ secara keseluruhan yaitu semakin ke arah laut konsentrasinya semakin berkurang. Pada lapisan dekat dasar ditemukan hubungan korelasi kuat antara fosfat dan MPT, yang dapat digunakan sebagai petunjuk bahwa MPT berkontribusi terhadap masukan fosfat.

\section{UCAPAN TERIMAKASIH}

Tulisan ini merupakan bagian dari penelitian yang dibiayai oleh Selain APBN DPA SUKPA dengan no kontrak, 16/UN7.5.10/PP/2019, FPIK, UNDIP, tahun anggaran 2019. Ucapan terimakasih kami sampaikan kepada pihak-pihak yang telah bersedia memberikan koreksi, kritik, saran dan masukan, sehingga penelitian dan penulisan makalah ini dapat terselesaikan.

\section{DAFTAR PUSTAKA}

Alaerts, G. \& Santika, S.S. 1987. Metoda Penelitian Air. Usaha Nasional. Surabaya.

[APHA] American Public Health Association. 1992. Standard methods for the examination of water and wastewater. 20th Ed. Washington DC.

Dzialowski, A.R., Wang, S.H., Lim, N.C., Beury, J.H. \& Huggins, D.G. 2008. Effects of sediment resuspensions on nutrient consentrations and algal biomass in reservoirs of the central plains. Lake and Reservoir Management, 24:313-320. 
Febrianto, S. \& Latifah, N. 2017. Pemetaan pola sebaran total suspended solid (tss) di Perairan Teluk Semarang menggunakan citra satelit landsat 7 etm dan landsat 8. Jurnal Harpodon Borneo, 10(1):56-60.

Gunduz, B., Aydın, F., Aydın, I. \& Hamamci, C. 2011. Study of phosphorus distribution in coastal surface sediment by sequential extraction procedure (NE Mediterranean Sea, Antalya-Turkey). Microchemical Journal, 98:72-76. doi: 10.1016/j.microc.2010.11.006.

Hendrawan, I.G., Uniluha, D., Ranu, I.P. \& Maharta, F. 2016. Karakteristik total padatan tersuspensi (total suspended solid) dan kekeruhan (turbidity) secara vertikal di Perairan Teluk Benoa, Bali. Journal of Marine and Aquatic Sciences, 2:29-33.

Maslukah, L., Indrayanti, E., \& Budhiono, S. 2014. Proses pasang surut dalam pola fluktuasi nutrien fosfat di Muara Sungai Demaan, Jepara. Buletin Oseanografi Marina, 3(1):25 -31.

Maslukah, L., Zainuri, M., Wirasatriya, A. \& Salma, U. 2019. Spatial distribution of chlorophyll-a and its relationship with dissolved inorganic phosphate influenced by rivers in the North Coast of Java. Journal of Ecological Engineering. 20(7):18-25.

Maslukah, L., Zainuri, M., Wirasatriya, A. \& Maisyarah, S. 2020. The relationship among dissolved inorganic phosphate, particulate inorganic phosphate, and chlorophyll-a in different seasons in the coastal seas of Semarang and Jepara. Journal of Ecological Engineering. 21(7):135-142.

Paerl, H.W. 2009. Controlling eutrophication along the freshwater-marine continuum: dual nutrient ( $\mathrm{n}$ and $\mathrm{p}$ ) reductions are essential. Estuaries and Coasts, 32:593-601. DOI : 10.1007/s12237009-9158-8.

Prartono, T., \& Hasena, T. 2009. Kinetic study of phosphor and nitrogen compound from sedimentary re-suspension, Jurnal IImu dan Teknologi Laut Tropis, 1(1):1-8. DOI : 10.29244/jitkt.v1i1.7933.

Prayitno, H.B. \& Afdal. 2019. Spatial distributions of nutrients and chlorophyll-a: a possible occurrence of phosphorus as a eutrophication determinant of the Jakarta Bay. Jurnal IImu dan Teknologi Kelautan Tropis, 11(1): 1-12. DOI: 10.29244/jitkt.v11i1.21971.

Prasetiyo, B.A., Rochaddi, B., \& Satriadi, A. 2019. Aplikasi citra sentinel-2 untuk pemetaan sebaran material padatan tersuspensi di Muara Sungai Wulan Demak. Journal of Marine Research, 8(4):379-386.

Prep. 2009. State of the Estuaries Report. Piscataqua Region Estuaries Partnership, University of New Hampshire, Durham, NH. Published

Pristiawan, H., Suryoputro, A.A.D., \& Nugroho, D. 2015. Pemetaan muatan padatan tersuspensi di perairan Muara Banjir Kanal Barat Semarang menggunakan data satelit landsat 8. Jurnal Oseanografi, 4(1): 280-28.

Satriadi, A \& Widada, S. 2004. Distribusi Muatan Padatan Tersuspensi di Muara Sungai Bodri, Kabupaten Kendal. Imu Kelautan, 9(2):101-107.

Shabari, A.R., Satriadi, A. \& Atmodjo, W. 2019. Padatan tersuspensi yang dipengaruh oleh proses pasang surut di Perairan Kaliboyo, Kabupaten Pekalongan. Journal of Marine Research, 8(4):393-401.

Subiyanto, S. 2017. Remote sensing and water quality indicators in the west flood canal Semarang City: Spatio-temporal structures of lansat-8 derived chlorophyll-a and total suspended solids. The 5th Geoinformation Science Symposium. IOP Conf. Series: Earth and Environmental Science, 98:012055. DOI :10.1088/1755-1315/98/1/012055

Tungka, A.W., Haeruddin \& Ain, C. 2016. Konsentrasi nitrat dan ortophosphat di muara sungai Banjir Kanal Barat dan kaitannya dengan kelimpahan fitoplankton harmful alga blooms (HABs). Saintek Perikanan, 12(1): 40-46. DOI : 10.14710/ijfst.12.1.40-46

Ulqodry, T.Z., Yulisman, Y., Muhammad, S. \& Santoso, S. 2010. Karakteristik dan sebaran nitrat, fosfat dan oksigen terlarut di Perairan Karimunjawa, Jawa Tengah. Jurnal Penelitian Sains. 13(1):35-41. 